\title{
Dual Roles of CD40 on Microbial Containment and the Development of Immunopathology in Response to Persistent Fungal Infection in the Lung
}

\author{
Gwo-Hsiao Chen, ${ }^{* \dagger}$ John J. Osterholzer, ${ }^{* \dagger}$ \\ Mun Y. Choe, ${ }^{*}$ Roderick A. McDonald, ${ }^{*}$ \\ Michal A. Olszewski, ${ }^{, \dagger}$ Gary B. Huffnagle, ${ }^{* \ddagger}$ \\ and Galen B. Toews ${ }^{\star \dagger}$ \\ From the Division of Pulmonary and Critical Care Medicine,* \\ Department of Internal Medicine, and the Department of \\ Microbiology and Immunology, ${ }^{\ddagger}$ University of Michigan Medical \\ School, Ann Arbor; and the Pulmonary Section, ${ }^{\dagger}$ Department of \\ Veterans Affairs Ann Arbor Healthcare System, Ann Arbor, \\ Michigan
}

Persistent pulmonary infection with Cryptococcus neoformans in C57BL/6 mice results in chronic inflammation that is characterized by an injurious Th2 immune response. In this study, we performed a comparative analysis of cryptococcal infection in wild-type versus CD40-deficient mice (in a C57BL/6 genetic background) to define two important roles of $\mathrm{CD} 40$ in the modulation of fungal clearance as well as Th2-mediated immunopathology. First, CD40 promoted microanatomic containment of the organism within the lung tissue. This protective effect was associated with: i) a late reduction in fungal burden within the lung; ii) a late accumulation of lung leukocytes, including macrophages, $\mathrm{CD}^{+} \mathrm{T}$ cells, and CD8+ T cells; iii) both early and late production of tumor necrosis factor- $\alpha$ and interferon- $\gamma$ by lung leukocytes; and iv) early IFN- $\gamma$ production at the site of $T$ cell priming in the regional lymph nodes. In the absence of CD40, systemic cryptococcal dissemination was increased, and mice died of central nervous system infection. Second, CD40 promoted pathological changes in the airways, including intraluminal mucus production and subepithelial collagen deposition, but did not alter eosinophil recruitment or the alternative activation of lung macrophages. Collectively, these results demonstrate that CD40 helps limit progressive cryptococcal growth in the lung and protects against lethal central nervous system dissemination. $\mathrm{CD} 40$ also promotes some, but not all, elements of Th2-mediated immunopathology in response to persistent fungal infection in the lung. (Am J Pathol 2010, 177:2459-2471; DOI: 10.2353/ajpath.2010.100141)

CD40, a 48-kDa type I transmembrane protein and member of the tumor necrosis factor receptor family, is a well-described costimulatory molecule expressed on $B$ cells, dendritic cells (DC), macrophages, basophils, and platelets as well as nonhematopoietic cells including fibroblasts, epithelial, and endothelial cells. The ligand for CD40, known as CD154 or CD40L, is a type II transmembrane protein member of the tumor necrosis factor (TNF) superfamily expressed primarily by activated $T$ cells, B cells, and platelets. ${ }^{1-3}$ CD40 can be induced on DC, monocytes, and macrophages under inflammatory conditions. ${ }^{4,5}$ Signaling via the CD40/CD40L pathway exerts numerous biological effects including: i) increased cytokine expression (especially TNF- $\alpha$ and Th1 cytokines interleukin (IL)-12 and interferon (IFN)- $\alpha$ ) and nitric oxide production; ii) upregulation of additional costimulatory molecules (CD80 and CD86) on antigen-presenting cells (APC); iii) enhanced cell survival (particularly of B and $T$ cells, DC, and endothelial cells); iv) Ig isotype switching; and $v$ ) somatic hypermutation of Ig. ${ }^{1,4,5}$

The CD40/CD40L signaling pathway contributes to adaptive Th1 immune responses required to clear Leishmanisa spp., ${ }^{6-8}$ Trypanosoma spp.,${ }^{6-9}$ Shistosoma mansoini, ${ }^{10}$ and the fungi Candida albicans ${ }^{11}$ and Pneumocystis spp. ${ }^{12}$ The enhanced production of IFN- $\gamma, \mathrm{TNF}-\alpha$, and nitric oxide associated with CD40/CD40L signaling is

Supported in part by grants from the National Heart, Lung, and Blood Institute (R01-HL51082) (G.B.T.); the National Institute of Allergy and Infectious Diseases (R01-Al059201) (G.B.H.); and the Department of Veterans Affairs (Merit grant, to G.B.T. and M.A.O.; Career Development Award, to J.J.O.). M.Y.C. was supported by the Undergraduate Research Opportunity Program at University of Michigan.

G.-H.C. and J.J.O. contributed equally to this manuscript.

Accepted for publication July 19, 2010

Address reprint requests to Galen B. Toews, M.D., Division of Pulmonary and Critical Care Division, Department of Internal Medicine, University of Michigan Medical School, 6220 MSRB III, Box 0624, 1150 W. Medical Center Dr., Ann Arbor, Ml 48109. E-mail: gtoews@umich.edu. 
thought to be responsible for this protective effect. However, other studies have suggest that CD40/CD40L signaling is not required for successful host defense against Listeria monocytogenes, ${ }^{13,14}$ Toxoplasma gondi, ${ }^{15}$ lymphocytic choriomeningitis virus, ${ }^{16,17}$ or the fungus Hisoplasma capsulatum. ${ }^{18,19}$ In models of Mycobacterium spp. infection, CD40 appears dispensable for clearance of an i.v. infection, ${ }^{20,21}$ but essential for clearing the organism in response to aerosolized infection in the lungs. ${ }^{22,23}$ Thus, the role of CD40 in antimicrobial host defense varies and depends not only on the specific pathogen but also on the primary site of infection.

Cryptococcus neoformans, an opportunistic fungal pathogen acquired through inhalation, causes significant morbidity and mortality primarily in patients with AIDS, lymphoid or hematological malignancies, or patients receiving immunosuppressive therapy secondary to autoimmune disease or organ transplantation..$^{24,25}$ Infection in non-immunocompromised patients has been reported. ${ }^{26-28}$ Murine models of cryptococcal infection in $\mathrm{CBA} / \mathrm{J}$ or $\mathrm{BALB} / \mathrm{c}$ mice demonstrate that development of a Th1 antigen-specific immune response characterized by IFN- $\gamma$ production and classical activation of macrophages is required to eradicate the organism. ${ }^{29-40}$ In contrast, a model of persistent cryptococcal infection has been developed using C57BL/6 mice; ${ }^{41-47}$ this model reflects many features observed in humans diagnosed with allergic bronchopulmonary mycosis. ${ }^{48}$ Specifically, these mice fail to clear the organism from the lung and develop characteristic Th2-mediated immunopathology including: i) tissue eosinophilia; ii) airway hyperreactivity, mucus production, and fibrosis; and iii) alternative macrophage activation associated with YM1 crystal deposition.

The molecular mechanisms responsible for the immunopathologic response associated with persistent cryptococcal infection are not clearly defined. These features are abrogated in the absence of $\mathrm{IL}-4,{ }^{45}$ whereas more severe Th2-mediated lung injury occurs in the absence of IFN- $\gamma^{29,41}$ TNF- $\alpha$ exerts a protective effect by enhancing IFN- $\gamma$ production and the subsequent classical activation of lung macrophages. ${ }^{31,35,49,50}$ Lymphocytes are critical mediators of this Th2 response as the pathological features of chronic cryptococcal infection are substantially diminished in CD4 T cell-depleted mice despite no change in fungal clearance. ${ }^{42}$

Although interactions between CD4 T cells and APC are critical determinants of $\mathrm{T}$ cell polarization in response to cryptococcal lung infection, ${ }^{49,51-55}$ the contribution of specific costimulatory molecules including the CD40/ CD40L signaling pathway has not been fully elucidated. In vitro studies suggest that activation of the CD40/CD40L pathway in response to Cryptococcus promotes IFN- $\gamma$ production by $\mathrm{T}$ cells and TNF- $\alpha$, and nitric oxide (NO) production by monocytes. ${ }^{56}$ In the absence of CD4OL, primary pulmonary infection with a weakly virulent strain of $C$. neoformans was associated with impaired fungal clearance; however, measurements of immune function at the site of infection in the lung or evidence of systemic fungal dissemination were not evaluated. ${ }^{57}$ The potential to target CD40 therapeutically is highlighted by studies showing that treatment of mice with disseminated or intracerebral cryptococcal infection with an agonist antibody to CD40 in combination with IL-2 improves survival. ${ }^{58,59}$ In this study, we used gene-targeted CD40-deficient mice (on a C57BL/6 genetic background), a clinically relevant model, and assessments of immune function and histopathology in the lung to identify two unique roles for the CD40-signaling pathway in response to persistent cryptococcal lung infection.

\section{Materials and Methods}

\section{Mice}

$\mathrm{CD} 40^{-/-}$mice (B6.129P2-Cd40 tm1Kik/J) and wild type $\left(\mathrm{CD} 40^{+/+}\right.$) mice (C57BL/6J), used as control, were purchased from The Jackson Laboratory (Bar Harbor, ME). Mice were housed at the University of Michigan Unit for Laboratory Animal Medicine facilities (Ann Arbor, MI), which is fully accredited by the American Association for Accreditation of Laboratory Animal Care. Mice were kept under specific pathogen-free conditions in enclosed filter top cages, and provided standard animal chow and chlorinated tap water ad libitum. Mice were 8-12 weeks of age at the time of infection and there were no agerelated differences in the responses of these mice to $C$. neoformans infection. Experiments were approved by the Animal Care and Use Committee at the University of Michigan.

\section{C. neoformans}

C. neoformans strain 52D was obtained from the American Type Culture Collection (ATCC 24067; Manassas, VA); this strain displayed a smooth colony morphology when grown on Sabouraud dextrose agar. For the infection, yeast that were recovered from $10 \%$ glycerol stocks were grown to stationary phase (at least 72 hours) at $36^{\circ} \mathrm{C}$ in Sabouraud dextrose broth (1\% neopeptone, 2\% dextrose; Difco, Detroit, MI) on a shaker. The cultures were then washed in nonpyrogenic saline (Travenol, Deerfield, IL), counted on a hemocytometer, and diluted to $3.3 \times 10^{5}$ yeast cells $/ \mathrm{ml}$ in sterile nonpyrogenic saline.

\section{Intratracheal Inoculations}

Mice were anesthetized by i.p. injection of pentobarbital ( $0.074 \mathrm{mg} / \mathrm{g}$ weigh of mice) and restrained on a surgical board. A small incision was made through the skin over the trachea and the underlying tissue was separated. A bent 30-gauge needle (BD Biosciences, Rutherford, NJ) was attached to a tuberculin syringe (BD Biosciences, Franklin Lakes, $\mathrm{NJ}$ ) filled with the diluted $\mathrm{C}$. neoformans culture. The needle was inserted into the trachea, and 30 $\mu \mathrm{l}$ of inoculums were dispensed into the lungs $\left(10^{4}\right.$ yeast cells). The skin was closed with cyanoacrylate adhesive. The mice recovered with minimal visible trauma. 


\section{Colony-Forming Unit Assay}

For determination of fungal colony-forming unit (CFU) in lung and lung-associated lymph nodes (LALN), small aliquots were collected from lung digests or LALN suspensions (described below). For determination of CFU in the spleen and brain, the organs were excised, placed in $2 \mathrm{ml}$ of sterile water, and homogenized. Ten microliter aliquots of the lungs, LALN, spleen, and brain were plated on Sabouraud dextrose agar plates in duplicate serial 10 -fold dilutions and incubated at room temperature. C. neoformans colonies were counted 3 days later and the number of CFU were determined on a per organ basis. C. neoformans colonies recovered from all organs retained their smooth morphology.

\section{Leukocyte Isolation from Lungs}

The lungs from each mouse were excised, washed in PBS, minced with scissors, and enzyme-digested at $37^{\circ} \mathrm{C}$ for 30-35 minutes in $15 \mathrm{ml} /$ lung of digestion buffer (RPMI 1640 medium, 5\% FCS, antibiotics, $1 \mathrm{mg} / \mathrm{ml}$ collagenase (Boehringer Mannheim Biochemical, Chicago, IL), and $30 \mu \mathrm{g} / \mathrm{ml}$ DNase (Sigma-Aldrich, St. Louis, MO)). The cell suspension and tissue fragments were further dispersed by repeated aspiration through the bore of a 10-ml syringe and were centrifuged. Erythrocytes in the cell pellets were lysed by addition of $3 \mathrm{ml}$ of $\mathrm{NH}_{4} \mathrm{Cl}$ buffer $\left(0.829 \% \mathrm{NH}_{4} \mathrm{Cl}, 0.1 \% \mathrm{KHCO}_{3}\right.$, and $0.0372 \% \mathrm{Na}_{2} \mathrm{EDTA}$ $(\mathrm{pH}$ 7.4)) for 3 minutes followed by a 10-fold excess of RPMI. Cells were resuspended and a second cycle of syringe dispersion, and filtration through a sterile 100- $\mu \mathrm{m}$ nylon screen (Nitex Kansas City, MO) was performed. The filtrate was centrifuged for 30 minutes at $1500 \times g$ in the presence of $20 \%$ Percoll (Sigma-Aldrich) to separate leukocytes from cell debris and epithelial cells. Leukocyte pellets were resuspended in $5 \mathrm{ml}$ of media and enumerated on a hemocytometer following dilution in trypan blue.

\section{Leukocyte Isolation from LALN}

LALN were processed into a cell suspension by gently passing tissues through nylon mesh. Cells were then washed and resuspended in complete RPMI 1640 medium. Total viable cell numbers were assessed by trypan blue exclusion and counting on a hemocytometer.

\section{Leukocyte Cultures and Assessment of Cytokine Production}

Leukocytes isolated from the lung or LALN were cultured $\left(5 \times 10^{6} / \mathrm{ml}\right)$ for 24 hours in 24-well plates with $2 \mathrm{ml}$ of complete RPMI 1640 medium at $37^{\circ} \mathrm{C}$ and $5 \% \mathrm{CO}_{2} .1 \times$ $10^{7}$ heat-killed C. neoformans/ml were included in LALN cultures. Culture supernatants were harvested at 24 hours and assayed for cytokines TNF- $\alpha$, IFN- $\gamma$, IL-4, and IL-5 (OptEIA kit; BD Pharmingen, San Diego, CA) by sandwich ELISA following the manufacturer's protocols.

\section{Histology}

Lungs were fixed by inflation with 10\% neutral-buffered formalin. Brains were carefully excised and immersed in $10 \%$ neutral-buffered formalin. After paraffin embedding, $5-\mu \mathrm{m}$ lung sections were cut and stained with H\&E, periodic acid-Schiff (to stain mucus and mucus-secreting goblet cells), or Masson's trichrome (collagen deposition stains blue). Lung cysts were quantified by counting the number of cysts within the lung per low-power field $(\times 100$ magnification) in separate regions of inflamed lung (13 total fields assessed, $n=2$ mice per strain). Medium power ( $\times 200$ magnification) fields were used when needed to further distinguish individual cysts. Numbers of goblet cells were quantified by counting the number of goblet cells with identifiable mucus production visible per high-power field ( $\times 400$ magnification; 10 total fields assessed, $n=2$ mice per strain). Brain sections were stained with a combination of mucicarmine and H\&E. Sections were analyzed with light microscopy and microphotographs taken using Nikon Digital Microphotography system DFX1200 and ACT-1 software.

\section{Visual Identification of Leukocyte Populations}

To obtain differential cell counts of lung cell suspensions isolated from the lung digest, samples were cytospun (Shandon Cytospin, Pittsburgh, PA) onto glass slides and stained by a modification of the Diff-Quik whole blood stain (Diff-Quik; VWR Scientific Products, West Chester, $P A$ ). Samples were fixed/prestained for 2 minutes in a onestep methanol based Wright-Giemsa stain (Harleco, EM Diagnostics, Gibbstown, NJ) rinsed in water and stained using steps two and three of the Diff-Quik stain. This modification of the Diff-Quik stain procedure improves the resolution of eosinophils from neutrophils in the mouse. $A$ total of 200 cells were counted for each sample from randomly chosen, high power microscope fields.

\section{Flow Cytometric Analysis of Lymphocyte Subsets}

Lung cells $\left(5 \times 10^{5} /\right.$ sample) were incubated for $30 \mathrm{~min}$ utes on ice in a total volume of $120 \mu$ l of staining buffer (FA buffer (Difco) with $0.1 \%$ Sodium Azide, and $1 \%$ fetal calf serum). Each sample was incubated with $0.12 \mu \mathrm{g}$ of PE-labeled anti-CD45 (30-F11) and with either $0.25 \mu \mathrm{g}$ of one of the following FITC-labeled mAbs: RM4-5 (antiCD4), 53-6.7 (anti-CD8), RA3-6B2 (anti-B220), or isotypematched rat IgG. The samples were washed in staining buffer and fixed with $1 \%$ paraformaldehyde (Sigma) in buffered saline. Stained samples were stored in the dark at $4^{\circ} \mathrm{C}$ until analyzed on a flow cytometer (Coulter Elite ESP, Palo Alto, CA). All mAb reagents were purchased from BD Pharmingen. Samples were gated for CD45positive cells and then analyzed for staining by the specific FITC-labeled antilymphocyte markers. The absolute number of each lymphocyte subset in the sample was obtained by the percentage of that type of lymphocyte subset multiplied by the total number of leukocytes. 


\section{Macrophage Isolation}

Total lung leukocytes obtained (as above) from the lungs of either $\mathrm{CD} 40^{+/+}$mice $(n=4)$ or CD40 ${ }^{-1-}$ mice $(n=3)$ at 5 weeks postinfection (wpi) were depleted of granulocytes (including neutrophils) using an EasySep PE antiLy-6G-magnetic selection kit according to the manufacturer's protocols (StemCell Technologies, Vancouver, British Columbia, Canada). Cells expressing CD11b were subsequently positively isolated using EasySep FITC anti-CD11b-magnetic selection kit and cultured on plastic at $2 \times 10^{6} \mathrm{cells} / \mathrm{ml}$ for 1 hour at $37^{\circ} \mathrm{C}$. Nonadherent cells containing residual granulocytes, monocytes, and DC were discarded, and the resultant adherent macrophage population was removed by cell scraping following incubation with $1 \mathrm{mmol} / \mathrm{L}$ EDTA for 20 minutes. Visual inspection using cytospins confirmed that $>95 \%$ of cells displayed macrophage morphology. Macrophages were pooled and used thereafter for RNA extraction and PCR analysis (see below).

\section{Real-Time RT-PCR}

Total macrophage-specific RNA was prepared using RNeasy Plus Mini Kit (Qiagen, Valencia, CA) and firststrand cDNA was synthesized using SuperScriptIII (Invitrogen, Carlsbad, CA) according to the manufacturer's instructions. Cytokine mRNA was quantified with SYBR Green-based detection using an MX 3000P system (Stratagene, La Jolla, CA) according to the manufacturer's protocols. Forty cycles of PCR $\left(94^{\circ} \mathrm{C}\right.$ for 15 seconds followed by $60^{\circ} \mathrm{C}$ for 30 seconds and $72^{\circ} \mathrm{C}$ for $30 \mathrm{sec}$ onds) were performed on a cDNA template. The mRNA levels were expressed as a ratio of their relative abundance to the housekeeping gene, glyceraldehyde-3phosphate dehydrogenase. The following murine oligonucleotide primers were used for RT-PCR analysis: arginase (Arg-1) sense, 5'-CAGAAGAATGGAAGAGTCAG-3'; Arg-1 antisense, 5'-CAGATATGCAGGGAGTCACC-3'; inducible NO synthase (iNOS) sense, 5'-TTTGCTTCCATGCTAATGCGAAAG-3'; iNOS antisense, 5'-GCTCTGTTGAGGTCTAAAGGCTCCG-3' .

\section{Total Serum IgE Analysis}

Blood was obtained by tail vein bleed of the mice. Following centrifugation to separate cells, serum was removed, and total IgE concentrations were assessed using an IgE-specific sandwich ELISA (BD Pharmingen).

\section{Survival Postcryptococcal Lung Infection}

CD40 ${ }^{+/+}$mice and CD40 ${ }^{-1-}$ mice were inoculated by the intratracheal route with $10^{4} \mathrm{CFU}$ of $\mathrm{C}$. neoformans and monitored daily thereafter until death.

\section{Statistical Analysis}

Means, SEM, and unpaired Student's $t$-test results were used to compare data obtained from $\mathrm{CD}_{40}{ }^{+/+}$mice and
$\mathrm{CD}_{40}{ }^{-1-}$ mice. Whenever variance was unequal (assessed by F-test), a $t$-test for samples with unequal variance was substituted in place of a standard homscedastic $t$-test. Pooling of data occurred only if corresponding data sets between experiments were similar $(P>0.05$ by unpaired Student's $t$-test). Survival postinfection was assessed using Kaplan-Meier plots followed by log rank tests. $P$ values of 0.05 were considered statistically different.

\section{Results}

\section{CD40 Promotes Microanatomic Containment of C. neoformans in the Lung}

Our first objective was to determine whether CD40 deficiency affected the rate of clearance of $C$. neoformans from the lungs of infected mice. $\mathrm{CD}_{4} \mathrm{O}^{+/+}$mice (wildtype; C57BL/6) and CD40 ${ }^{-1-}$ mice (C57BL/6 genetic background) were inoculated by the intratracheal route with $10^{4}$ organisms. The fungal burden in the lung was assessed by CFU assay at 2 and 5 wpi as described. As expected, a sizeable fungal burden was present in the lungs of $\mathrm{CD}_{40} 0^{+/+}$mice at 2 and 5 wpi (Figure 1) consistent with this model of persistent fungal infection. ${ }^{29,43,45,47}$ In CD40 ${ }^{-1-}$ mice, the fungal burden was similar to that of $\mathrm{CD} 40^{+/+}$mice at 2 wpi but was significantly increased $\left(10\right.$-fold) relative to $\mathrm{CD} 40^{+/+}$ mice at 5 wpi.

These differences in microbial burden motivated us to investigate whether CD40 deficiency altered lung immunopathology associated with persistent cryptococcal lung infection. Histological lung sections obtained from $\mathrm{CD}_{40}{ }^{+/+}$mice and $\mathrm{CD} 40^{-1-}$ mice at 2 and 5 wpi with $C$. neoformans were evaluated by light microscopy. Lung sections taken from $\mathrm{CD}_{40}{ }^{+/+}$mice at 2 wpi (Figure 2, A and $\mathrm{C}$ ) revealed consolidated infiltrates of granulomatous inflammation comprised of eosinophils, lymphocytes,

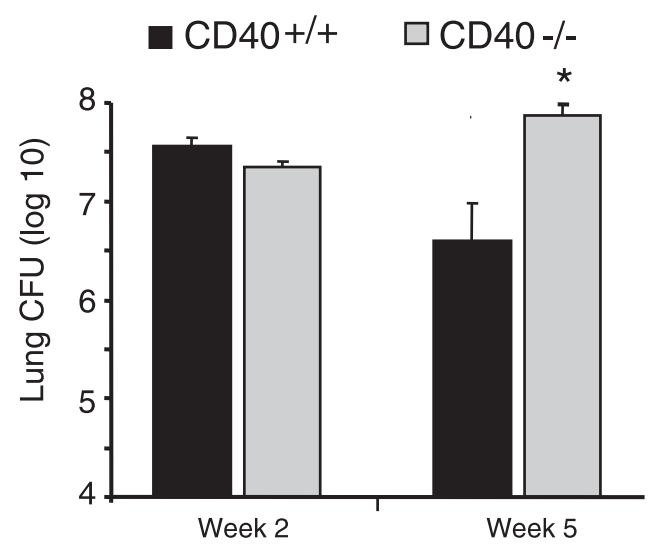

Figure 1. CD 40 protects against progressive fungal growth in the lungs of mice with persistent cryptococcal lung infection. CD $40^{+/+}$mice and $\mathrm{CD} 40^{-1-}$ mice were intratracheally infected with $10^{4} \mathrm{C}$. neoformans, and lungs were harvested at either 2 or $5 \mathrm{wpi}$. Aliquots from organ digests were plated on Sabouraud dextrose agar in serial 10-fold dilutions, and total CFU per lung were detected. Note the $y$ axis is presented in log scale and begins at the inoculating dose $\left(10^{4}\right)$ of $C$. neoformans. Data pooled from two separate matched experiments are expressed as the mean CFU per organ \pm SEM; $n=8-9$ mice per strain at each time point; ${ }^{*} P<0.05$ for comparison between $\mathrm{CD} 40^{+/+}$mice (black bars) versus $\mathrm{CD} 40^{-/-}$mice (gray bars). 

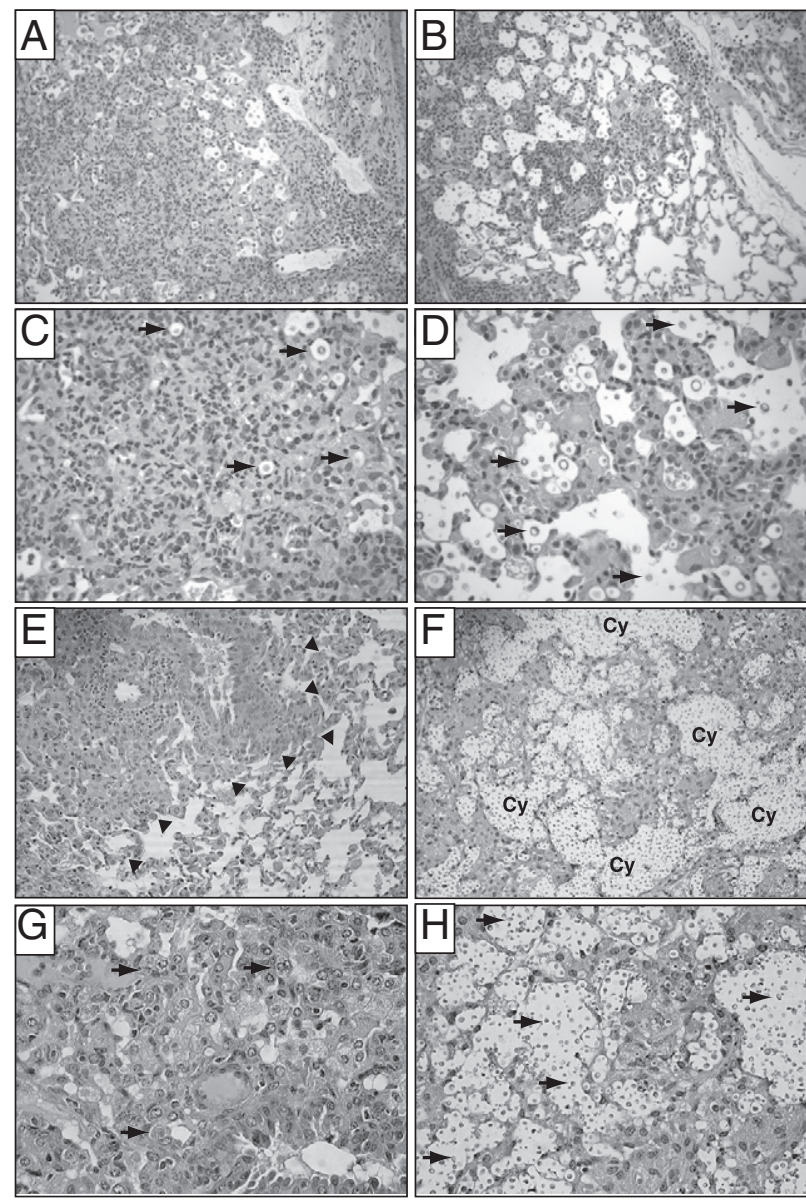

Figure 2. CD40 promotes microanatomic containment of C. neoformans in the lungs of mice with persistent cryptococcal lung infection. CD $40^{+/+}$mice and $\mathrm{CD} 40^{-1-}$ mice were intratracheally infected with $10^{4} \mathrm{C}$. neoformans, and lung sections were obtained at $2 \mathrm{wpi}(\mathbf{A}-\mathbf{D})$ or $5 \mathrm{wpi}(\mathbf{E}-\mathbf{H})$. Representative photomicrographs (H\&E staining) of lungs from $\mathrm{CD}_{4} 0^{+/+}$mice $(\mathbf{A}, \mathbf{C}, \mathbf{E}$, and $\mathbf{G})$ and $\mathrm{CD}_{40}^{--}$mice $(\mathbf{B}, \mathbf{D}, \mathbf{F}$, and $\mathbf{H})$ at medium $(\mathbf{A}, \mathbf{B}, \mathbf{E}$, and $\mathbf{F} ; \times 200)$ and high $(\mathbf{C}, \mathbf{D}, \mathbf{G}$, and $\mathbf{H} ; \times 400)$ magnification. Note the dense foci of inflammation observable in the lungs of $\mathrm{CD} 40^{+/+}$mice at 2 wpi (A and $\mathbf{C}$ ). Infiltrates contain granulocytes, macrophages, and small mononuclear cells, most identifiable cryptococci are located intracellularly (arrows; C). By 5 wpi, focal infiltrates in $\mathrm{CD}_{4} 0^{+/+}$mice $(\mathbf{E}$ and $\mathbf{G}$ ) are clearly separate from adjacent areas of normal lung (arrowheads denote this border; $\mathbf{E}$ ). Infiltrates contain numerous macrophages; some appearing multinucleated (arrows, G). In contrast, more diffuse inflammation and extracellular cryptococci (arrows; $\mathbf{D}$ and $\mathbf{H}$ ) are observed in the lungs of $\mathrm{CD} 40^{-/-}$mice at $2 \mathrm{wpi}(\mathbf{B}$ and $\mathbf{D})$ and $5 \mathrm{wpi}(\mathbf{F}$ and $\mathbf{H})$. By $5 \mathrm{wpi}$, numerous extracellular cryptococci coalescing within transparent capsular material form destructive cysts $(\mathrm{Cy} ; \mathbf{F})$ within the lung parenchyma.

large activated macrophages, and multinucleated giant cells. Very few extracellular cryptococci were visible. In contrast, inflammation in the lungs of $\mathrm{CD} 40^{-1-}$ mice was less organized (Figure 2, B and D). Infiltrates were loosely distributed throughout the lung and extracellular cryptococci were more numerous within alveolar spaces (relative to lungs from $\mathrm{CD}_{4} 0^{+/+}$mice).

At 5 wpi, the observed pattern of inflammation in the lung parenchyma of $\mathrm{CD}_{4} 0^{+/+}$mice was similar to that observed at 2 wpi and included dense infiltrates in which eosinophils and macrophages were readily identified. These leukocytes tightly infiltrated alveolar compartments and sequestered infected areas from adjacent intact lung tissue (Figure 2E). Although intracellular cryptococci were visible within macrophages, extracellular cryptococci were rare (Figure 2G). In contrast, lung sections obtained from $\mathrm{CD} 40^{-1-}$ mice at 5 wpi revealed numerous extracellular cryptococci. In addition, large conglomerates of extracellular cryptococci suspended in transparent capsular material were identified suggestive of cyst formation (Figure 2, F and $\mathrm{H}$ ). Cysts, late manifestations of uncontrolled infections associated with failed containment of $C$. neoformans, were abundant in $\mathrm{CD} 40^{-1-}$ mice (9.1 \pm 1.4 cysts per low-power field) but absent in $\mathrm{CD} 40^{+/+}$mice $(0.0 \pm 0.0$ per low-power field). Infiltrates contained numerous eosinophils and neutrophils whereas the number of macrophages and lymphocytes appeared reduced (relative to $\mathrm{CD}_{40}{ }^{+/+}$mice). Collectively, our assessment of fungal burden in the lung and histological analysis suggests that CD40 expression promotes microanatomic containment of $C$. neoformans within the lung at early and late time points postinfection.

\section{CD40 Promotes the Late Accumulation of Lung Leukocytes but Does Not Alter Granulocyte Recruitment in Mice with Cryptococcal Lung Infection}

We next sought to determine whether differences in lung leukocyte populations might account for this impairment in cryptococcal containment we observed in CD40-deficient mice. Consistent with our histological analysis, persistent inflammation was noted in $\mathrm{CD} 40^{+/+}$mice and $\mathrm{CD}_{40}^{-1-}$ mice at 2 and 5 wpi. Numbers of lung leukocytes were comparable in both strains of mice at 2 wpi; however, at 5 wpi, the total number of lung leukocytes was significantly decreased in $\mathrm{CD} 40^{-1-}$ mice (Figure $3 A$ ). This finding demonstrated that CD40-signaling promoted continued pulmonary leukocyte accumulation in the later stage of infection which could account for the improved containment of Cryptococcus (in $\mathrm{CD}_{4} 0^{+/+}$ mice) that we observed.

A subset analysis of lung leukocytes was performed (by visual identification using light microscopy as per Materials and Methods) to further investigate CD40-mediated host responses against $C$. neoformans. Eosinophils were readily identified in the lungs of $\mathrm{CD} 40^{+/+}$mice at both 2 and 5 wpi consistent with results of our histological evaluation and prior studies using this model system. In CD40 ${ }^{-1-}$ mice, no significant difference in the number of eosinophils (Figure 3B) or neutrophils (Figure 3C) was observed (relative to $\mathrm{CD} 40^{+/+}$mice) at either time point. Thus, accumulation of eosinophils and neutrophils to the lungs of cryptococcal-infected mice appeared independent of CD40 expression.

\section{CD40 Promotes the Late Accumulation of Macrophages but Does Not Affect Their Alternative Activation in Mice with Cryptococcal Lung Infection}

Our subset analysis was next used to identify differences in lung macrophage accumulation between cryptococ- 


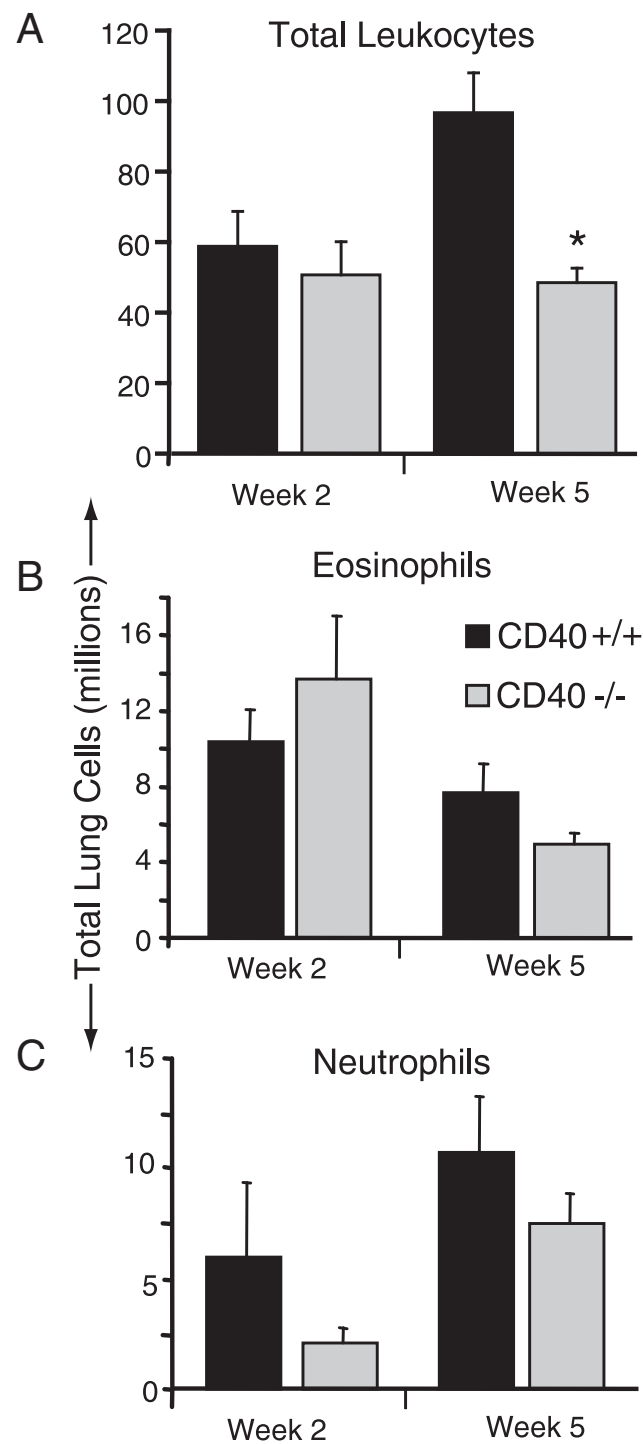

Figure 3. CD 40 promotes the late accumulation of lung leukocytes but does not alter granulocyte recruitment in mice with persistent cryptococcal lung infection. A-C: Lung leukocytes isolated from CD $40^{+/+}$mice and CD $40^{-1}$ mice at 2 and 5 weeks postintratracheal infection with $10^{4}$ C. neoformans were enumerated by visual identification (see Materials and Methods). Total leukocytes (A); total eosinophils (B); and total neutrophils per lung (C). Representative data from one experiment expressed as mean absolute numbers of recruited leukocytes per lung \pm SEM, $n=4-5$ mice per strain at each time point; ${ }^{*} P<0.05$ for comparison between $\mathrm{CD} 40^{+/+}$mice (black bars) versus $\mathrm{CD} 40^{-/-}$mice (gray bars). The experiment was repeated once in its entirety with similar results.

cal-infected $\mathrm{CD} 40^{+/+}$mice and CD40 ${ }^{-/-}$mice. No difference in lung macrophage numbers were identified at 2 wpi whereas a significant decrease in total lung macrophage numbers was noted at 5 wpi in $\mathrm{CD}_{40}^{-1-}$ mice (relative to $\mathrm{CD}_{40}{ }^{+/+}$mice) (Figure $4 \mathrm{~A}$ ).

Macrophages in the lungs of mice with persistent cryptococcal lung infection are alternatively activated. ${ }^{41,53}$ To determine whether CD40 expression affected macrophage activation in the current study, we compared mRNA expression of arginase (Arg-1; a marker of alternative activation) and iNOS (a marker of classical activation) in lung macrophages obtained from the lungs $\mathrm{CD} 40^{+/+}$mice or $\mathrm{CD} 40^{-1-}$ mice at 5 wpi with $C$. neofor- mans. Results demonstrate robust expression of arginase mRNA relative to that for iNOS in lung macrophages obtained from CD40 ${ }^{+/+}$mice and $\mathrm{CD} 40^{-/-}$mice (Figure 4B) consistent with alternative activation. Next, we evaluated lung sections from $\mathrm{CD}_{4} 0^{+/+}$mice at 5 wpi for additional evidence of alternative macrophage activation. Numerous large cells containing intracellular cryptococci and adjacent YM-1 crystals characteristic of alternativelyactivated macrophages were easily identified within inflammatory infiltrates (Figure 4, C-E). As expected, ${ }^{41,53}$ macrophages with a similar appearance and YM-1 crystals were present in the lungs of $\mathrm{CD}_{40}{ }^{+/+}$mice (data not shown). Collectively, these data show that CD40 expression promotes the late accumulation of lung macrophages but does not affect their alternative activation.

\section{CD40 Promotes Intraluminal Mucus Production and Subepithelial Collagen Deposition in the Airways of Mice with Persistent Cryptococcal Lung Infection}

Although fungal burden was increased in CD40-1- mice (relative to $\mathrm{CD}_{40}{ }^{+/+}$mice at $5 \mathrm{wpi}$ ), immunopathologic features of persistent cryptococcal lung infection were still present including tissue eosinophilia and alternative macrophage activation within alveolar infiltrates. We next sought to investigate whether CD40 expression affected Th2-associated manifestations of airway disease which include increased mucus production and subepithelial collagen deposition. ${ }^{45}$ Lung sections from CD $40^{+/+}$mice and $\mathrm{CD} 40^{-1-}$ mice at 5 wpi were stained with periodic acid Shiff (to identify mucus and mucus secreting goblet cells) or Masson's trichrome (to identify collagen). Results demonstrate abundant mucus production in the lungs of $\mathrm{CD}_{40} 0^{+/+}$mice, whereas a striking reduction in mucus-producing goblet cells was observed in the lungs of CD40-deficient mice (34.3 \pm 6.8 mucus-producing goblet cells per high-power field, $\mathrm{CD}_{4} 0^{+/+}$mice versus $0.3 \pm 0.3$ mucus-producing goblet cells per high-power field, CD40 ${ }^{-1-}$ mice; $P<0.05$; Figure 5, A and B). Similarly, collagen deposition in the subepithelial space and adjacent small blood vessels appeared prominent in the lungs of $\mathrm{CD}_{40} 0^{+/+}$mice (Figure $5 \mathrm{C}$ ) but markedly reduced in the lungs of infected $\mathrm{CD} 40^{-1-}$ mice (Figure 5D). These findings revealed an unexpected role for CD40 in promoting features of Th2-associated airway disease in mice with persistent cryptococcal lung infection.

\section{CD40 Promotes the Late Accumulation of Lung CD4 and CD8 T Cells in Mice with Persistent Cryptococcal Lung Infection}

Lymphocytes are the primary recipients of signals mediated by CD40-expressing APC. Therefore, we assessed lymphocyte populations in the lungs of $\mathrm{CD}_{4} 0^{+/+}$mice and $\mathrm{CD} 40^{-1-}$ mice using flow cytometric analysis. We observed a significant reduction in the total lymphocyte numbers present in the lungs of $\mathrm{CD}_{40}{ }^{-1-}$ mice relative to 
A

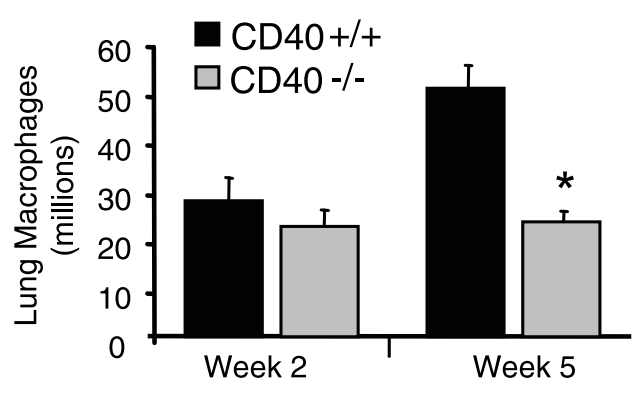

B

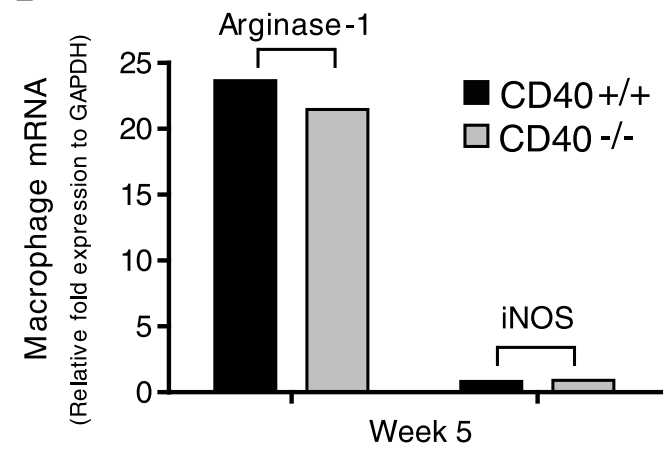

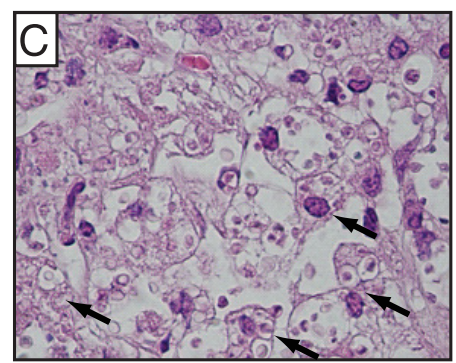
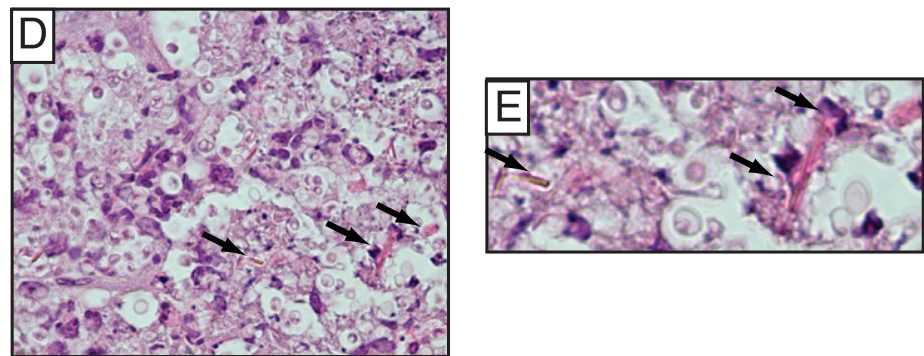

Figure 4. CD 40 promotes the late accumulation of lung macrophages but does not alter their alternatively activated phenotype in mice with persistent cryptococcal lung infection. A: Lung leukocytes isolated from CD $40^{+/+}$mice and CD $40^{-/-}$mice at 2 and 5 weeks postintratracheal infection with $10^{4} C$. neoformans were assessed for the presence of macrophages by visual identification. Representative data from one experiment expressed as mean absolute numbers of macrophages per lung \pm SEM, $n=4-5$ mice per strain at each time point; ${ }^{*} P<0.05$ for comparison between CD $40^{+/+}$mice (black bars) versus $\mathrm{CD} 40^{-1-}$ mice (gray bars). The experiment was repeated once in its entirety with similar results. B: Real-time RT-PCR analysis of lung macrophages (as described in Materials and Methods) pooled from either CD $40^{+/+}$mice $(n=4$; black bars $)$ or $\mathrm{CD} 40^{-1-}$ mice $(n=3$; gray bars $)$ and assessed for mRNA expression of either arginase-1 or iNOS relative to that of a housekeeping gene (glyceraldehyde-3-phosphate dehydrogenase (GAPDH)). Note the strong expression of arginase relative to that of iNOS in both strains of mice suggestive of alternative macrophage activation. C-E: Representative photomicrographs (H\&E staining; $\times 400$ magnification, $\mathbf{C}$ and $\mathbf{D} ; \times 800$ magnification, E) of lung sections isolated from CD $40^{-1-}$ mice at 5 wpi with $C$ neoformans. Note the presence of large cells containing intracellular cryptococci (arrows; C), a feature consistent with alternatively activated macrophages. Numerous YM1 crystals (arrows; D and E) characteristic of alternative macrophage activation are also identified.

CD40 ${ }^{+/+}$mice at 5 wpi (Figure 6A). Note that this difference was not apparent at an earlier time point (2 wpi). This difference in total lymphocytes was not due to impaired $B$ cell accumulation in the lung as numbers
$\mathrm{B} 220+\mathrm{B}$ cells were similar in $\mathrm{CD} 0^{+/+}$mice and $\mathrm{CD}_{40}{ }^{-1-}$ mice at 2 and 5 wpi (Figure 6B). CD40 expression did affect $B$ cell function as $\lg E$ production was completely abrogated in CD40 ${ }^{-1-}$ mice (data not shown)
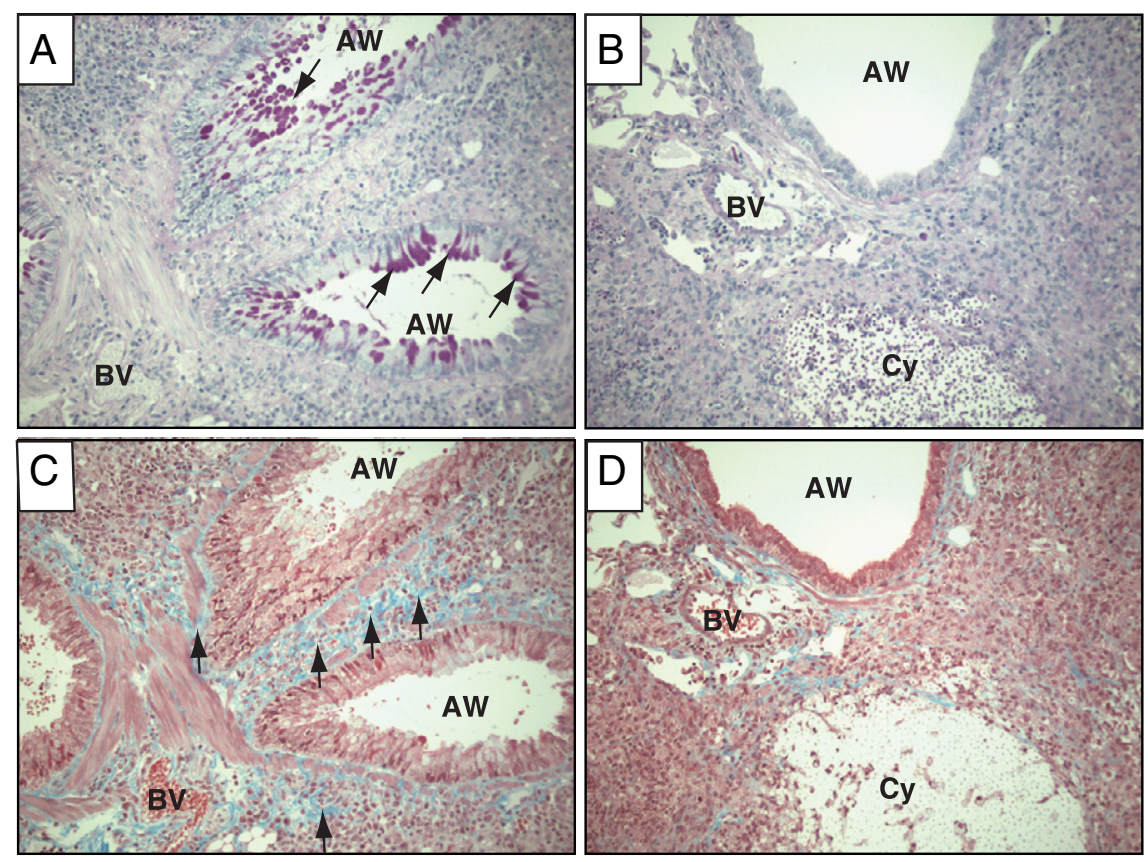

Figure 5. CD40 expression increases late airway mucus production and subepithelial collagen deposition in mice with cryptococcal lung infection. Representative photomicrographs $(\times 200$ magnification) of lung sections isolated from $\mathrm{CD} 40^{+/+}$ mice (A and $\mathbf{C}$ ) and $\mathrm{CD} 40^{-1-}$ mice $(\mathbf{B}$ and $\mathbf{D})$ at 5 weeks postintratracheal infection with $10^{4} \mathrm{C}$ neoformans. Sections were stained with periodic acidSchiff (A and B) to detect mucus (which stains purple) or Mason's trichrome (C and $\mathbf{D})$ to detect collagen (which stains blue). Note that infection in $\mathrm{CD} 40^{+/+}$mice $(\mathbf{A}$ and $\mathbf{C})$ results in strong periodic acid-Schiff staining (A; arrows within airways, AW) indicative of substantial mucus production. In addition, evidence of robust subepithelial collagen deposition ( $\mathbf{C}$; blue staining; arrows) is observed beneath airways and adjacent to blood vessels (BV). In contrast, infection in $\mathrm{CD} 40^{-/-}$mice (B and $\mathbf{D})$ reveals minimal airway mucus or subepithelial collagen deposition despite evidence of substantial inflammation. Note the destructive cryptococcal cyst (Cy) in these sections. 
A

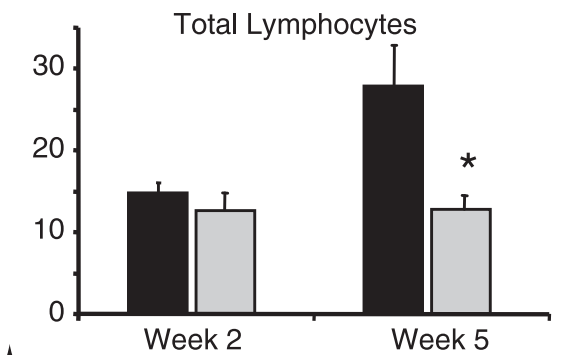

$\mathrm{B}$

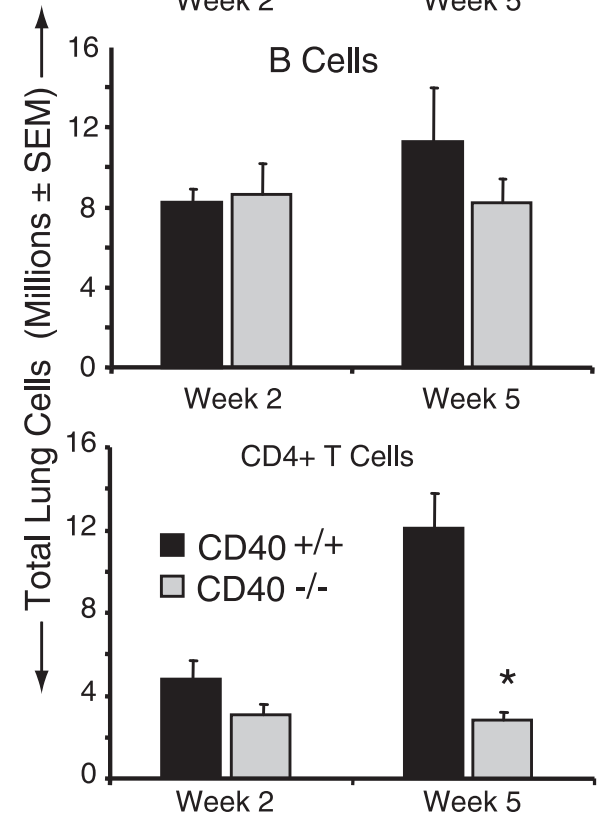

D

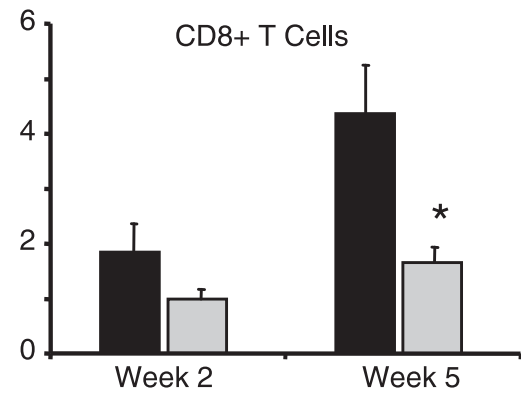

Figure 6. $\mathrm{CD} 40$ promotes the late accumulation of $\mathrm{CD}^{+}$and $\mathrm{CD} 8^{+} \mathrm{T}$ cells in mice with persistent cryptococcal lung infection. A-D: Lung leukocytes isolated from $\mathrm{CD} 40^{+/+}$mice and $\mathrm{CD} 40^{-1-}$ mice at 2 and 5 weeks postintratracheal infection with $10^{4} \mathrm{C}$. neoformans were assessed for the presence of lymphocytes by flow cytometric analysis. The percent-specific staining was multiplied by the total number of $\mathrm{CD} 45^{+}$leukocytes to obtain the total number of total lymphocytes $(\mathbf{A}), \mathrm{B} 220^{+} \mathrm{B}$ cells $(\mathbf{B}), \mathrm{CD}^{+}{ }^{+} \mathrm{T}$ cells $(\mathbf{C})$, and $\mathrm{CD}^{+} \mathrm{T}$ cells $(\mathbf{D})$. Representative data from one experiment expressed as mean absolute numbers of recruited leukocytes per lung \pm SEM, $n=4-5$ mice per strain at each time point; ${ }^{*} P<0.05$ for comparison between $\mathrm{CD} 40^{+/+}$mice (black bars) versus $\mathrm{CD} 40^{-/-}$mice (gray bars). The experiment was repeated once in its entirety with similar results.

consistent with the role for CD40 in mediating lg class switch. ${ }^{1}$

In contrast to the equivalent accumulation of B cells, both $\mathrm{CD}^{+}{ }^{+} \mathrm{T}$ cells and $\mathrm{CD}^{+} \mathrm{T}$ cells were significantly decreased in the lungs of $\mathrm{CD}_{4} 0^{-1-}$ mice relative to CD40 $+1+$ mice at 5 wpi (Figure 6, C and D). A trend toward a reduction in both subsets in $\mathrm{CD} 40^{-1-}$ mice was observed at 2 wpi. Thus, our results suggested that diminished $T$ cell accumulation might contribute to the defect in fungal containment or alterations in immunopathology observed in CD40-deficient mice infected with $C$. neoformans.

\section{CD40 Enhances Early and Late Expression of TNF- $\alpha$ and IFN- $\gamma$ in Lung Leukocytes Isolated from Mice with Persistent Cryptococcal Lung Infection}

We next evaluated whether the progressive cryptococcal growth observed in CD40-deficient mice was associated with diminished production of TNF- $\alpha$ or IFN- $\gamma$ by lung leukocytes as both cytokines are critically important for pulmonary clearance of $C$. neoformans and also contribute to microbial containment in our model of persistent cryptococcal lung infection. ${ }^{41,49,50}$ Results show that both TNF- $\alpha$ (Figure 7A) and IFN- $\gamma$ (Figure 7B) production were significantly decreased in lung leukocytes obtained from $\mathrm{CD}_{40}{ }^{-1-}$ mice (relative to leukocytes from $\mathrm{CD} 40^{+/+}$ mice) at 2 and 5 wpi (Figure 3).

Next, we determined whether CD40 expression affected production of two Th2-associated cytokines, IL-4 and IL-5. At 2 wpi, lung leukocyte, production of IL-4 was equivalent between both strains of mice (Figure 7C), whereas IL-5 production was significantly increased in CD40-1- mice (Figure 7D). At 5 wpi, small reductions in production of both $\mathrm{IL}-4$ and $\mathrm{IL}-5$ were observed in the lung leukocytes obtained from $\mathrm{CD}_{4} 0^{-1-}$ mice. Collectively, these data demonstrate that CD40 expression promotes early and late expression of the Th1-associated cytokines TNF- $\alpha$ and IFN- $\gamma$ in mice with persistent cryptococcal lung infection, whereas the effect of CD40 on Th2 cytokines was variable.

\section{CD40 Promotes Early Production of IFN- $\gamma$ and Inhibition of IL-5 in the LALN Nodes of Mice with Cryptococcal Lung Infection}

Our results revealed that differences in lung histology and cytokine production were already appreciable in the lungs of infected $\mathrm{CD} 40^{+/+}$mice and $\mathrm{CD} 40^{-/-}$mice at 2 wpi. The most striking of these differences was the decrease in TNF- $\alpha$ and IFN- $\gamma$ production by lung leukocytes in concert with their increased production of IL-5 (as described above; Figure 7) suggesting an effect of CD40 on $\mathrm{T}$ cell priming. We investigated this hypothesis by defining the early cytokine profile in the LALN, the site of $\mathrm{T}$ cell priming, in cryptococcal infected $\mathrm{CD} 40^{+/+}$mice and $\mathrm{CD} 40^{-1-}$ mice. Our results show that the production of IFN- $\gamma$ by LALN leukocytes obtained from CD40-1mice was markedly decreased, whereas IL-5 was increased (relative to LALN leukocytes from $\mathrm{CD}_{40}{ }^{+/+}$ mice) at 2 wpi (Figure 8). Thus, an effect of CD40 on early $\mathrm{T}$ cell priming in the LALN represents one important mechanism whereby CD40 may exert numerous profound alterations in the host response against $C$. neoformans in the later stages of persistent infection. 
A

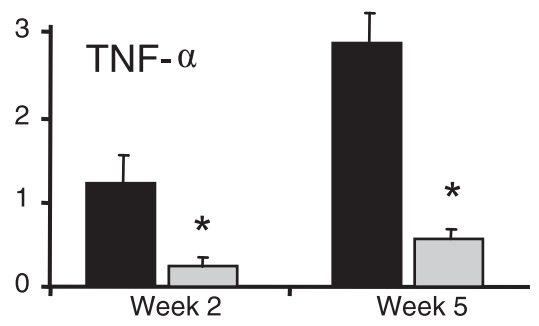

B

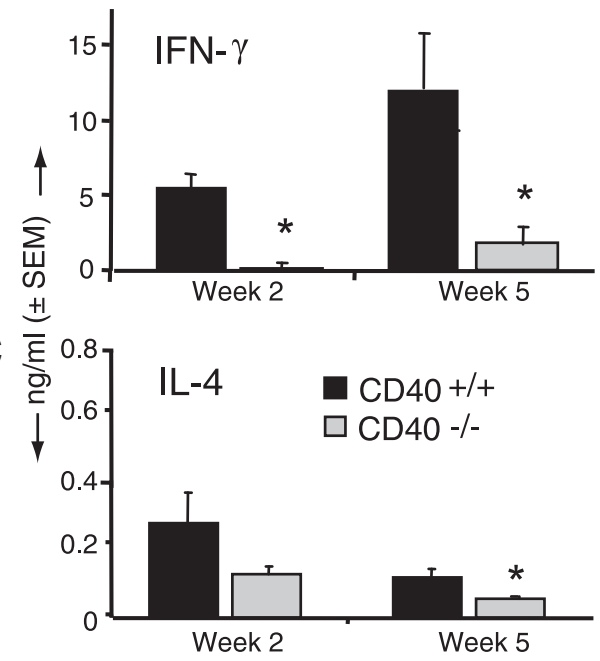

D

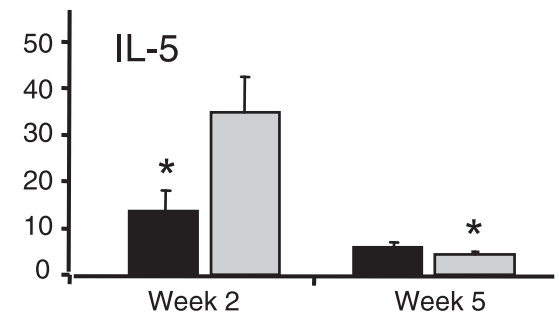

Figure 7. CD 40 promotes early and late production of TNF- $\alpha$ and IFN- $\gamma$ by lung leukocytes in mice with persistent cryptococcal lung infection. Lung leukocytes isolated from CD $40^{+/+}$mice and CD $40^{-/-}$mice at 2 and 5 weeks postintratracheal infection with $10^{4} \mathrm{C}$. neoformans were cultured overnight in vitro at $5 \times 10^{6}$ cells $/ \mathrm{ml}$ without additional stimulus. Culture supernatants were analyzed for TNF- $\alpha(\mathbf{A})$, IFN- $\gamma(\mathbf{B})$, IL-4 (C), or IL-5 (D) by ELISA as described in Materials and Methods. Data were pooled from two separate matched experiments and are expressed as the mean cytokine concentration (nanograms per milliliter) $\pm \mathrm{SEM} ; n=8-9$ mice per strain at each time point; ${ }^{*} P<0.05$ for comparison between $\mathrm{CD} 40^{+/+}$mice (black bars) versus $\mathrm{CD} 40^{-/-}$mice (gray bars).

\section{CD40 Protects against Systemic Cryptococcal Dissemination and Lethal Central Nervous System Infection}

Our final objective was to determine whether the impaired containment of $C$. neoformans within the lungs of $\mathrm{CD} 40^{-1-}$ mice altered systemic dissemination of the organism. Our results showed that at $2 \mathrm{wpi}$, no significant differences in fungal CFU were observed in the LALN or spleens of infected $\mathrm{CD} 40^{+/+}$mice versus $\mathrm{CD} 40^{-/-}$(data not shown). No dissemination to the brain occurred in either strain of mice at this time point (data not shown). However, by 5 wpi, numbers of cryptococcal organisms were significantly increased in the LALN, spleen, and brain of $\mathrm{CD} 40^{-/-}$mice relative to $\mathrm{CD} 40^{+/+}$mice (Figure 9A). Furthermore, whereas viable cryptococci were cul-

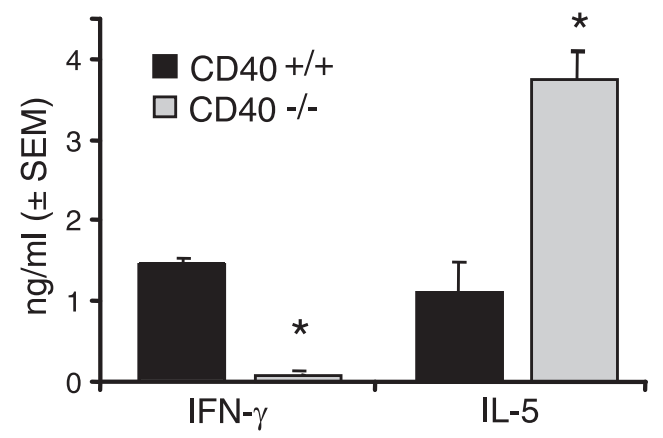

Figure 8. CD 40 promotes early IFN- $\gamma$ production in the LALN of mice infected with C. neoformans. Leukocytes isolated from the LALN of CD $40^{+/+}$ mice and $\mathrm{CD} 40^{-1-}$ mice at 2 weeks postintratracheal infection with $10^{4} \mathrm{C}$. neoformans were cultured overnight in vitro at $5 \times 10^{6}$ cells $/ \mathrm{ml}$ in the presence of $1 \times 10^{7}$ heat-killed C. neoformans $/ \mathrm{ml}$. Culture supernatants were analyzed for IFN- $\gamma$ and IL- 5 by ELISA as described in Materials and Methods. Data pooled from two separate matched experiments are expressed as the mean cytokine concentration (nanograms per milliliter) \pm SEM; $n=8-9$ mice per strain at each time point; ${ }^{*} P<0.05$ for comparison between $\mathrm{CD} 40^{+/+}$mice (black bars) versus $\mathrm{CD} 40^{-/-}$mice (gray bars).

tured from the brains of only $33 \%$ of $\mathrm{CD}_{4} \mathrm{O}^{+/+}$mice (three of nine), $100 \%$ of $\mathrm{CD}_{40} \mathrm{O}^{-1-}$ mice (8 of 8 ) had evidence of central nervous system (CNS) dissemination.

This finding of increased CNS dissemination in $\mathrm{CD} 40^{-1-}$ mice suggested that CD40 might profoundly affect whether mice survive cryptococcal lung infection as meningoencephalitis is a leading cause of morbidity and mortality both in humans ${ }^{60,61}$ and when studied in murine models. ${ }^{62}$ To investigate this hypothesis, $\mathrm{CD} 40^{+/+}$mice and $\mathrm{CD}_{40}{ }^{-1-}$ mice were infected by the intratracheal route with $10^{4} \mathrm{C}$. neoformans and followed thereafter for survival. At 6 wpi, CD40 $0^{+/+}$mice appeared active and healthy whereas $\mathrm{CD} 40^{-1-}$ mice began displaying lethargy, hunched posture, and gait disturbances. Histological analysis of brain tissue from $\mathrm{CD}_{4} 0^{+/+}$mice at this time point revealed normal brain architecture (Figure 9B, top panel). In contrast, numerous destructive cryptococcal cysts distributed throughout the brain were evident in sections obtained from moribund CD40 ${ }^{-1-}$ mice (Figure 9B, bottom panel). The experiment was terminated at 8 wpi at which time point only $40 \%$ (two of five) of $\mathrm{CD}_{40} \mathrm{O}^{-1-}$ mice remained alive (Figure $9 \mathrm{C}$ ) yet both had evidence of CNS infection $\left(2 \times 10^{4}\right.$ and $2 \times 10^{7}$ brain CFU, respectively). In contrast, $100 \%$ of $\mathrm{CD}_{4} \mathrm{O}^{+/+}$ mice (five of five) remained alive; $C$. neoformans could not be cultured from the brains of two of these mice, whereas three mice had evidence of CNS infection which was low $\left(2 \times 10^{2}, 2 \times 10^{2}\right.$, and $2 \times 10^{4}$ brain CFU, respectively). Thus, these results imply that the CD40-mediated containment of $C$. neoformans within the lung provides critical protection against systemic cryptococcal dissemination and lethal CNS infection.

\section{Discussion}

In this study, we used a well-described murine model to identify two important effects of the CD40-signaling pathway on the host response to persistent lung infection with the fungal pathogen, C. neoformans. First, CD40 enhances cryptococcal containment within the lung and 
A

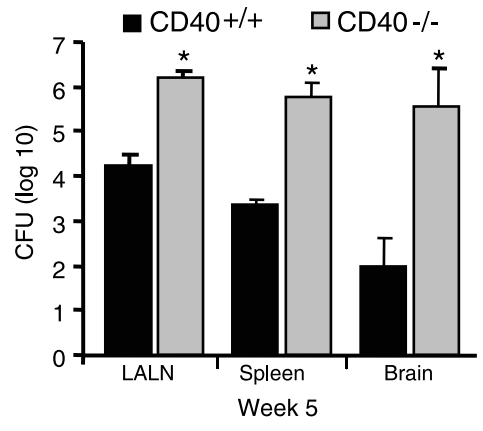

B
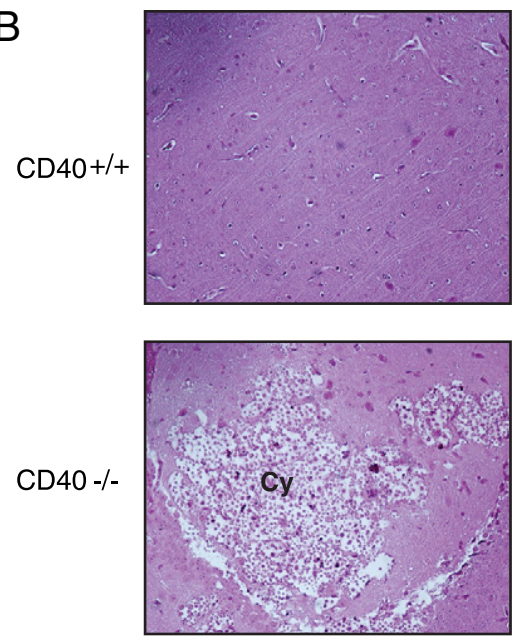

C

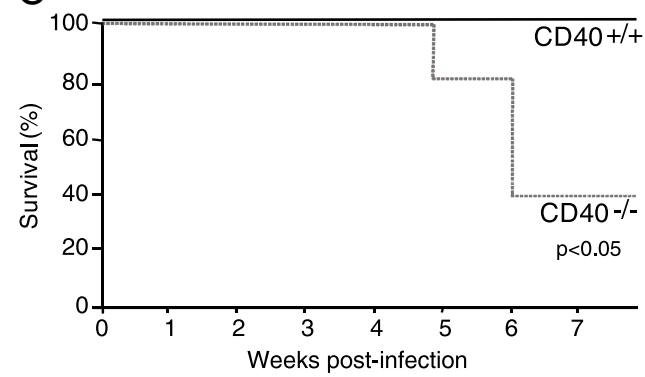

Figure 9. CD40 protects against systemic fungal dissemination and lethal CNS infection in mice with persistent cryptococcal lung infection. A-C: $\mathrm{CD} 40^{+/+}$mice and $\mathrm{CD} 40^{-/-}$mice were intratracheally infected with $10^{4} \mathrm{C}$. neoformans. A: The LALN, spleen, and brain were harvested at $5 \mathrm{wpi}$, and total CFU per organ were detected. Data pooled from two separate matched experiments are expressed as the mean CFU per organ \pm SEM, $n=8-9$ mice per strain at each time point; ${ }^{*} P<0.05$ for comparison between $\mathrm{CD} 40^{+/+}$ mice (black bars) versus CD $40^{-1-}$ mice (gray bars). B: Photomicrographs ( $\times 200$ magnification, H\&E staining) of cryptococcal-infected CD $40^{+/+}$mice (top panel) or $\mathrm{CD} 40^{-/-}$mice (bottom panel) at $6 \mathrm{wpi}$. Note the preserved CNS architecture in $\mathrm{CD} 40^{+/+}$mice, whereas numerous expansive cryptococcal cysts (Cy) are identified in the brains of $\mathrm{CD} 40^{-/-}$mice. C: Survival curves of $\mathrm{CD} 40^{+/+}$mice (solid black line) and $\mathrm{CD} 40^{-1-}$ mice (dashed gray line) at 8 wpi; $n=5$ mice per strain; $P<0.05$ by Kaplan-Meier analysis.

limits systemic dissemination and lethal CNS infection. This protective effect is associated with the formation of organized pulmonary infiltrates containing numerous macrophages and T cells, and the CD40-mediated production of two effector cytokines, TNF- $\alpha$ and IFN- $\gamma$. Second, CD40 signaling enhances some features of Th2-associated immunopathology associated with persistent cryptococcal lung infection including intraluminal mucus production and subepithelial collagen deposition, whereas CD40 does not alter eosinophil recruitment, alternative macrophage activation, or enhance early production of IL-4 or IL-5. Collectively, this study sheds important insight into the cellular and molecular mechanisms which define the complex interrelationship existent between mammalians hosts and persistent microbial pathogens in the lung.

Our data demonstrates a critical role for CD40 in protecting against the consequences of uncontrolled cryptococcal growth following pulmonary infection. We defined this protective effect of the CD40-signaling pathway using CD40-deficient mice. The lack of CD40 in these gene-targeted mice is specific, absolute, and irreversible; therefore the role of CD40 can be evaluated without concern for residual receptor function. Our model uses an encapsulated, moderately virulent strain (52D; ATCC 24067) of C. neoformans introduced via the respiratory route; this closely models the acquisition of disease in human hosts. ${ }^{63}$ Although CD40 expression does not affect the fungal burden in the lung 2 wpi, we observe focal infiltrates and diminished number of extracellular cryptococci in CD40-expressing mice at this time point suggesting an early effect of CD40 at the microanatomic level. This protective effect of CD40 on the pulmonary microenvironment is more apparent late (5 wpi) in the course of infection whereby fungal CFU in the lung has not increased, extracellular cryptococci are absent, and the organism appears entirely sequestered from normal lung by dense, macrophage-laden infiltrates. The consequences of failed cryptococcal containment are substantial in CD40-deficient mice. First, progressive cryptococcal growth is associated with destruction of the pulmonary parenchyma by expansive cryptococcal cysts. Second, systemic dissemination of the organism to other organs, including the brain, is increased. The significance of this finding is underscored by the increased mortality we observed in $\mathrm{CD}_{40}{ }^{-1-}$ mice; a finding which further extends studies showing that CNS dissemination is highly associated with lethal meningitis in mice and humans. ${ }^{61-65}$ These findings illustrate the necessity of microbial containment despite an inability of the host to entirely clear the organism (ie, persistent infection).

We investigated whether CD40-mediated containment of $C$. neoformans results from enhanced expression of effector cytokines at the site of infection in the lung. CD40 expression increases TNF- $\alpha$ production by lung leukocytes at both early and late time points postinfection. TNF- $\alpha$ has potent anticryptococcal effects in both models of self-limited ${ }^{49}$ and persistent cryptococcal lung infection. ${ }^{50}$ Impaired TNF- $\alpha$ production in CD40-deficient mice may reflect both reduced production by individual cells, including macrophages, ${ }^{5}$ and a net decrease in total macrophage numbers. In addition, we determined that IFN- $\gamma$, a potent stimulator of macrophage effector function, ${ }^{5}$ is also increased in lung leukocytes obtained from CD40-expressing mice at both early and late time points postinfection. The association between impaired IFN- $\gamma$ production and loss of cryptococcal containment we identify in CD40-deficient mice supports the results of our prior studies demonstrating a requirement for IFN- $\gamma$ in containing fungal growth, even in a Th2 predominant pulmonary microenvironment. ${ }^{29,41,50}$ The decrease in 
IFN- $\gamma$ production by CD40-deficient lung leukocytes likely reflects both diminished production by individual lymphocytes, ${ }^{1}$ and the net decrease in $\mathrm{CD} 4^{+} \mathrm{T}$ cells and $\mathrm{CD}^{+} \mathrm{T}$ cells we observe in $\mathrm{CD} 40^{-1-}$ mice at 5 wpi.

Our finding of impaired IFN- $\gamma$ production by leukocytes from the LALN further suggests a defect at the level of T cell priming by APC. DC in LALN of cryptococcal-infected mice express CD40 in vivo, ${ }^{43,52,66}$ and stimulation of DC with C. neoformans further upregulates CD40 expression in vitro. ${ }^{49,66} \mathrm{IL}-5$ production by leukocytes in the LALN (or the lungs) of $\mathrm{CD}_{40} 0^{-1-}$ mice is not diminished suggesting that CD40-deficiency does not globally suppress $T$ cell cytokine production in this model. APC located outside the LALN might also contribute to the CD40-dependent responses we report in this study. We have observed CD40 expression by recruited lung DC, ${ }^{52,66}$ exudate macrophages (manuscript submitted for publication) and by B cells in mice with cryptococcal lung infection (unpublished observations). In addition, a study by Vecchiarelli et $\mathrm{al}^{56}$ implicates human peripheral blood monocytes as important contributors to CD40-dependent anti cryptococcal immune responses. We believe this model is well suited to further study the mechanisms through which CD40 influences the host response against persistent fungal infection in the lung.

The protective effect of the CD40-signaling pathway we identify in this study may not apply to all fungal pathogens and may vary with the specific pathogen and the route of infection. CD40L is also required for resolution of murine Pneumocystis pneumonia. ${ }^{67}$ However, adaptive immune responses against Histoplasma capsulatum are not impaired in CD40L-deficient mice. ${ }^{19}$ In that study, $\mathrm{H}$. capsulatum infection was established by the i.v. route and fungal burden was assessed in the spleen. Studies using murine models of Mycobacterium spp. infection suggest that $\mathrm{CD} 40 / \mathrm{CD} 40 \mathrm{~L}$ have a protective role against inhalational, ${ }^{22,23}$ but not i.v. infection. ${ }^{20,21}$ Although the CD40signaling pathway remains an attractive target of novel therapeutics, ${ }^{58,59}$ these findings highlight the importance of evaluating these strategies using carefully constructed and clinically relevant animal models of infection.

The second important finding of our study is that CD40, in addition to its protective effect on cryptococcal containment, enhances some features of Th2-associated immunopathology in this model of persistent fungal lung infection. Evidence of airway pathology, including goblet cell hyperplasia, intraluminal mucus production, smooth muscle hypertrophy, and subepithelial collagen deposition are well described features of Th2 immune responses associated with persistent cryptococcal lung infection in mice (current study and as reported). ${ }^{41,42,52,53}$ Strikingly, these features, also described in models of allergic lung disease, ${ }^{68}$ are almost completely absent in CD40-deficient mice. To our knowledge, this CD40-dependent enhancement of airway disease has not been previously reported in mice with persistent lung infection. This result might reflect our use of a live microbial pathogen as Hogan et al reported that airway hyperreactivity and morphology were not attenuated in CD40-deficient mice when studied in a model of antigen (ovalbumin)-induced allergic airways disease. ${ }^{69}$ In contrast, a study by Hellings et al ${ }^{70}$ reported that morphological features of airway inflammation were reduced by agonist stimulation with a CD40 antibody in a similar model system. Similar to these studies and others, we found that CD40-deficient mice do not produce IgE, likely as a result of impaired class switching. Thus, our results contribute to a larger body of literature investigating the causative role (and potential for therapeutic targeting) of costimulatory molecules in the development of immune-mediated airway disease (reviewed in Ref. 71).

Our results reveal that CD40 does not promote all features of Th2 immune responses associated with persistent cryptococcal lung. In this study, we report that the alternative activation of lung macrophages in response to a microbial challenge in vivo is CD40-independent. Alternative macrophage activation associated with arginase expression and YM1 crystal deposition is a prominent feature of lung disease associated with persistent cryptococcal lung infection and other forms of allergic lung disease. ${ }^{41,53}$ Alternative macrophage activation contributes to impaired microbial killing and may result in lung damage due to crystal deposition. ${ }^{72}$ This finding contrasts with the known role of the CD40-signaling pathway in promoting many features of classical macrophage activation (including TNF- $\alpha$ and NO production; reviewed in Ref. 5). We also show that tissue eosinophilia is comparable in both strains of infected mice; a similar finding was observed in a model of ovalbumin-induced allergic disease. ${ }^{69}$ These CD40-independent features of persistent cryptococcal lung infection may reflect our finding that CD40-deficiency did not impair the early production of Th2 cytokines by leukocytes obtained from the lung (IL-4 and IL-5) or LALN (IL-5).

In summary, our results demonstrate that CD40 expression is critically important to limit progressive fungal growth, parenchymal lung destruction, and lethal CNS dissemination in mice with persistent cryptococcal lung infection. This protective effect on microbial containment must be balanced against our finding that CD40 also contributes to some, but not all, immunopathologic features of persistent infection including airway mucus production and subepithelial collagen deposition. These results not only have direct relevance to the development of novel therapeutics targeting the CD40-signaling pathway but more broadly highlight the complex interrelationship that exists between mammalian hosts and persistent microbial pathogens.

\section{Acknowledgments}

We thank Rod McDonald and Nicole Falkowski for assistance in different parts of this project.

\section{References}

1. Elgueta R, Benson MJ, de Vries VC, Wasiuk A, Guo Y, Noelle RJ: Molecular mechanism and function of CD40/CD40L engagement in the immune system. Immunol Rev 2009, 229:152-172

2. Quezada SA, Jarvinen LZ, Lind EF, Noelle RJ: CD40/CD154 interac- 
tions at the interface of tolerance and immunity. Annu Rev Immunol 2004, 22:307-328

3. van Kooten C, Banchereau J: CD40-CD40 ligand. J Leukoc Biol 2000, 67:2-17

4. Ma DY, Clark EA: The role of CD40 and CD154/CD40L in dendritic cells. Semin Immunol 2009, 21:265-272

5. Suttles J, Stout RD: Macrophage CD40 signaling: a pivotal regulator of disease protection and pathogenesis. Semin Immunol 2009, 21:257-264

6. Campbell KA, Ovendale PJ, Kennedy MK, Fanslow WC, Reed SG, Maliszewski CR: CD40 ligand is required for protective cell-mediated immunity to Leishmania major. Immunity 1996, 4:283-289

7. Kamanaka M, Yu P, Yasui T, Yoshida K, Kawabe T, Horii T, Kishimoto T, Kikutani H: Protective role of CD40 in Leishmania major infection at two distinct phases of cell-mediated immunity. Immunity 1996, 4:275-281

8. Soong L, Xu JC, Grewal IS, Kima P, Sun J, Longley BJ Jr, Ruddle NH, McMahon-Pratt D, Flavell RA: Disruption of CD40-CD40 ligand interactions results in an enhanced susceptibility to Leishmania amazonensis infection. Immunity 1996, 4:263-273

9. Chaussabel D, Jacobs $F$, de Jonge J, de Veerman M, Carlier $Y$, Thielemans K, Goldman M, Vray B: CD40 ligation prevents Trypanosoma cruzi infection through interleukin-12 upregulation. Infect Immun 1999, 67:1929-1934

10. MacDonald AS, Patton EA, La Flamme AC, Araujo MI, Huxtable CR, Bauman B, Pearce EJ: Impaired Th2 development and increased mortality during Schistosoma mansoni infection in the absence of CD40/CD154 interaction. J Immunol 2002, 168:4643-4649

11. Netea MG, Meer JW, Verschueren I, Kullberg BJ: CD40/CD40 ligand interactions in the host defense against disseminated Candida albicans infection: the role of macrophage-derived nitric oxide. Eur $\mathrm{J} \mathrm{Im-}$ munol 2002, 32:1455-1463

12. Hernandez-Novoa B, Bishop L, Logun C, Munson PJ, Elnekave E, Rangel ZG, Barb J, Danner RL, Kovacs JA: Immune responses to Pneumocystis murina are robust in healthy mice but largely absent in CD40 ligand-deficient mice. J Leukoc Biol 2008, 84:420-430

13. Hamilton SE, Tvinnereim AR, Harty JT: Listeria monocytogenes infection overcomes the requirement for CD40 ligand in exogenous antigen presentation to CD8 ${ }^{+}$T cells. J Immunol 2001, 167:5603-5609

14. Shedlock DJ, Whitmire JK, Tan J, MacDonald AS, Ahmed R, Shen H: Role of CD4 T cell help and costimulation in CD8 T cell responses during Listeria monocytogenes infection. J Immunol 2003, 170: 2053-2063

15. Gazzinelli RT, Hieny S, Wynn TA, Wolf S, Sher A: Interleukin 12 is required for the T lymphocyte-independent induction of interferon $\gamma$ by an intracellular parasite and induces resistance in T cell-deficient hosts, Proc Natl Acad Sci USA 1993, 90:6115-6119

16. Borrow P, Tishon A, Lee S, Xu J, Grewal IS, Oldstone MB, Flavell RA: CD40L-deficient mice show deficits in antiviral immunity and have an impaired memory CD8 ${ }^{+}$CTL response. J Exp Med 1996, 183:2129-2142

17. Whitmire JK, Slifka MK, Grewal IS, Flavell RA, Ahmed R: CD40 liganddeficient mice generate a normal primary cytotoxic $T$ lymphocyte response but a defective humoral response to a viral infection. J Virol 1996, 70:8375-8381

18. Wheat LJ, Durkin M, Schnizlein-Bick C, Bassey E, Kohler S, Connolly P, Goldberg J, Garringer T, Brizendine E, Thomas EK: Effect of CD40 ligand on the course of murine histoplasmosis. Med Mycol 2002, 40:501-505

19. Zhou P, Seder RA: CD40 ligand is not essential for induction of type 1 cytokine responses or protective immunity after primary or secondary infection with histoplasma capsulatum. J Exp Med 1998, 187: $1315-1324$

20. Campos-Neto A, Ovendale P, Bement T, Koppi TA, Fanslow WC, Rossi MA, Alderson MR: CD40 ligand is not essential for the development of cell-mediated immunity and resistance to Mycobacterium tuberculosis. J Immunol 1998, 160:2037-2041

21. Larkin R, Benjamin CD, Hsu YM, Li Q, Zukowski L, Silver RF: CD40 ligand (CD154) does not contribute to lymphocyte-mediated inhibition of virulent Mycobacterium tuberculosis within human monocytes. Infect Immun 2002, 70:4716-4720

22. Florido M, Goncalves AS, Gomes MS, Appelberg R: CD40 is required for the optimal induction of protective immunity to Mycobacterium avium. Immunology 2004, 111:323-327
23. Lazarevic V, Myers AJ, Scanga CA, Flynn JL: CD40, but not CD40L, is required for the optimal priming of $\mathrm{T}$ cells and control of aerosol $\mathrm{M}$. tuberculosis infection. Immunity 2003, 19:823-835

24. Kwon-Chung KJ, Sorrell TC, Dromer F, Fung E, Levitz SM Cryptococcosis: clinical and biological aspects. Med Mycol 2000, 38(Suppl 1):205-213

25. Shoham S, Levitz SM: The immune response to fungal infections. Br J Haematol 2005, 129:569-582

26. Hoang LMN, Maguire JA, Doyle P, Fyfe M, Roscoe DL: Cryptococcus neoformans infections at Vancouver Hospital and Health Sciences Centre (1997-2002): epidemiology, microbiology and histopathology. J Med Microbiol 2004, 53:935-940

27. Hofman V, Venissac N, Mouroux C, Butori C, Mouroux J, Hofman P. [Disseminated pulmonary infection due to Cryptococcus neoformans in a nonimmunocompromised patient]. French. Ann Pathol 2004, 24:187-191

28. Zahra LV, Azzopardi CM, Scott G: Cryptococcal meningitis in two apparently immunocompetent Maltese patients. Mycoses 2004, 47:168-173

29. Chen GH, McDonald RA, Wells JC, Huffnagle GB, Lukacs NW, Toews GB: The $\gamma$ interferon receptor is required for the protective pulmonary inflammatory response to Cryptococcus neoformans. Infect Immun 2005, 73:1788-1796

30. Herring AC, Hernandez Y, Huffnagle GB, Toews GB: Role and development of $\mathrm{TH} 1 / \mathrm{TH} 2$ immune responses in the lungs. Semin Respir Crit Care Med 2004, 25:3-10

31. Herring AC, Lee J, McDonald RA, Toews GB, Huffnagle GB: Induction of interleukin-12 and $\gamma$ interferon requires tumor necrosis factor $\alpha$ for protective T1-cell-mediated immunity to pulmonary Cryptococcus neoformans infection. Infect Immun 2002, 70:2959-2964

32. Hoag KA, Lipscomb MF, Izzo AA, Street NE: IL-12 and IFN- $\gamma$ are required for initiating the protective Th1 response to pulmonary cryptococcosis in resistant C.B-17 mice. Am J Respir Cell Mol Biol 1997, 17:733-739

33. Huffnagle GB, Lipscomb MF: Cells and cytokines in pulmonary cryptococcosis. Res Immunol 1998, 149:387-396; discussion 512-384

34. Huffnagle GB, Lipscomb MF, Lovchik JA, Hoag KA, Street NE: The role of $\mathrm{CD}^{+}$and $\mathrm{CD}_{8}{ }^{+} \mathrm{T}$ cells in the protective inflammatory response to a pulmonary cryptococcal infection. J Leukoc Biol 1994, 55:35-42

35. Huffnagle GB, Toews GB, Burdick MD, Boyd MB, McAllister KS, McDonald RA, Kunkel SL, Strieter RM: Afferent phase production of TNF- $\alpha$ is required for the development of protective T cell immunity to Cryptococcus neoformans. J Immunol 1996, 157:4529-4536

36. Kawakami K, Qureshi MH, Zhang T, Koguchi Y, Yara S, Takeda K, Akira S, Kurimoto M, Saito A: Involvement of endogenously synthesized interleukin (IL)-18 in the protective effects of IL-12 against pulmonary infection with Cryptococcus neoformans in mice. FEMS Immunol Med Microbiol 2000, 27:191-200

37. Kawakami K, Tohyama M, Xie Q, Saito A: IL-12 protects mice against pulmonary and disseminated infection caused by Cryptococcus neoformans. Clin Exp Immunol 1996, 104:208-214

38. Mody CH, Lipscomb MF, Street NE, Toews GB: Depletion of CD4 ${ }^{+}$ $\left({\mathrm{L} 3 \mathrm{~T} 4^{+}}^{+}\right)$lymphocytes in vivo impairs murine host defense to Cryptococcus neoformans. J Immunol 1990, 144:1472-1477

39. Mody CH, Paine R, 3rd, Jackson C, Chen GH, Toews GB: CD8 cells play a critical role in delayed type hypersensitivity to intact Cryptococcus neoformans. J Immunol 1994, 152:3970-3979

40. Mody CH, Paine R, 3rd, Jackson CJ, Toews GB: CD8 cells mediate delayed hypersensitivity following intrapulmonary infection with Cryptococcus neoformans. Chest 1993, 103:118S

41. Arora S, Hernandez Y, Erb-Downward JR, McDonald RA, Toews GB, Huffnagle GB: Role of IFN- $\gamma$ in regulating T2 immunity and the development of alternatively activated macrophages during allergic bronchopulmonary mycosis. J Immunol 2005, 174:6346-6356

42. Arora S, McDonald RA, Toews GB, Huffnagle GB: Effect of a CD4depleting antibody on the development of Cryptococcus neoformans-induced allergic bronchopulmonary mycosis in mice. Infect Immun 2006, 74:4339-4348

43. Chen GH, McNamara DA, Hernandez Y, Huffnagle GB, Toews GB, Olszewski MA: Inheritance of immune polarization patterns is linked to resistance versus susceptibility to Cryptococcus neoformans in a mouse model. Infect Immun 2008, 76:2379-2391

44. Chen GH, Olszewski MA, McDonald RA, Wells JC, Paine R, 3rd, 
Huffnagle GB, Toews GB: Role of granulocyte macrophage colonystimulating factor in host defense against pulmonary Cryptococcus neoformans infection during murine allergic bronchopulmonary mycosis. Am J Pathol 2007, 170:1028-1040

45. Hernandez Y, Arora S, Erb-Downward JR, McDonald RA, Toews GB, Huffnagle GB: Distinct roles for IL-4 and IL-10 in regulating T2 immunity during allergic bronchopulmonary mycosis. J Immunol 2005, 174:1027-1036

46. Hoag KA, Street NE, Huffnagle GB, Lipscomb MF: Early cytokine production in pulmonary Cryptococcus neoformans infections distinguishes susceptible and resistant mice. Am J Respir Cell Mol Biol 1995, 13:487-495

47. Huffnagle GB, Boyd MB, Street NE, Lipscomb MF: IL-5 is required for eosinophil recruitment, crystal deposition, and mononuclear cell recruitment during a pulmonary Cryptococcus neoformans infection in genetically susceptible mice (C57BL/6). J Immunol 1998, 160:2393-2400

48. Gibson PG: Allergic bronchopulmonary aspergillosis. Semin Respir Crit Care Med 2006, 27:185-191

49. Herring AC, Falkowski NR, Chen GH, McDonald RA, Toews GB, Huffnagle GB: Transient neutralization of tumor necrosis factor $\alpha$ can produce a chronic fungal infection in an immunocompetent host: potential role of immature dendritic cells. Infect Immun 2005, 73:39-49

50. Milam JE, Herring-Palmer AC, Pandrangi R, McDonald RA, Huffnagle GB, Toews GB: Modulation of the pulmonary type $2 \mathrm{~T}$ cell response to Cryptococcus neoformans by intratracheal delivery of a tumor necrosis factor $\alpha$-expressing adenoviral vector. Infect Immun 2007 75:4951-4958

51. Bauman SK, Nichols KL, Murphy JW: Dendritic cells in the induction of protective and nonprotective anticryptococcal cell-mediated immune responses. J Immunol 2000, 165:158-167

52. Osterholzer JJ, Curtis JL, Polak T, Ames T, Chen GH, McDonald R, Huffnagle GB, Toews GB: CCR2 mediates conventional dendritic cell recruitment and the formation of bronchovascular mononuclear cell infiltrates in the lungs of mice infected with Cryptococcus neoformans. J Immunol 2008, 181:610-620

53. Osterholzer JJ, Surana R, Milam JE, Montano GT, Chen GH, Sonstein J, Curtis JL, Huffnagle GB, Toews GB, Olszewski MA: Cryptococcal urease promotes the accumulation of immature dendritic cells and a nonprotective T2 immune response within the lung. Am J Pathol 2009, 174:932-943

54. Siegemund S, Alber G: Cryptococcus neoformans activates bone marrow-derived conventional dendritic cells rather than plasmacytoid dendritic cells and down-regulates macrophages. FEMS Immunol Med Microbiol 2008, 52:417-427

55. Wozniak KL, Vyas JM, Levitz SM: In vivo role of dendritic cells in a murine model of pulmonary cryptococcosis. Infect Immun 2006, 74:3817-3824

56. Vecchiarelli A, Retini C, Pietrella D, Monari C, Kozel TR: T lymphocyte and monocyte interaction by CD40/CD40 ligand facilitates a lymphoproliferative response and killing of Cryptococcus neoformans in vitro. Eur J Immunol 2000, 30:1385-1393
57. Pietrella D, Lupo P, Perito S, Mosci P, Bistoni F, Vecchiarelli A: Disruption of CD40/CD40L interaction influences the course of Cryptococcus neoformans infection. FEMS Immunol Med Microbiol 2004, 40:63-70

58. Zhou Q, Gault RA, Kozel TR, Murphy WJ: Immunomodulation with CD40 stimulation and interleukin-2 protects mice from disseminated cryptococcosis. Infect Immun 2006, 74:2161-2168

59. Zhou Q, Gault RA, Kozel TR, Murphy WJ: Protection from direct cerebral cryptococcus infection by interferon- $\gamma$-dependent activation of microglial cells. J Immunol 2007, 178:5753-5761

60. Berkefeld J, Enzensberger W, Lanfermann H: Cryptococcus meningoencephalitis in AIDS: parenchymal and meningeal forms. Neuroradiology 1999, 41:129-133

61. Lee SC, Dickson DW, Casadevall A: Pathology of cryptococcal meningoencephalitis: analysis of 27 patients with pathogenetic implications. Hum Pathol 1996, 27:839-847

62. Olszewski MA, Noverr MC, Chen GH, Toews GB, Cox GM, Perfect JR, Huffnagle GB: Urease expression by Cryptococcus neoformans promotes microvascular sequestration, thereby enhancing central nervous system invasion. Am J Pathol 2004, 164:1761-1771

63. Casadevall A, Perfect JR: Cryptococcus neoformans. Human Cryptococcosis edited by A Casadevall and JR Perfect. Washington DC ASM Press, 1998, 541 p, pp 407-456

64. Kovacs JA, Kovacs AA, Polis M, Wright WC, Gill VJ, Tuazon CU, Gelmann EP, Lane HC, Longfield R, Overturf G, et al.: Cryptococcosis in the acquired immunodeficiency syndrome. Ann Intern Med 1985, 103:533-538

65. Zhang $\mathrm{Y}$, Wang F, Tompkins KC, McNamara A, Jain AV, Moore BB, Toews GB, Huffnagle GB, Olszewski MA: Robust Th1 and Th17 immunity supports pulmonary clearance but cannot prevent systemic dissemination of highly virulent Cryptococcus neoformans H99. Am J Pathol 2009, 175:2489-2500

66. Osterholzer JJ, Chen GH, Olszewski MA, Curtis JL, Huffnagle GB, Toews GB: Accumulation of $\mathrm{CD} 11 \mathrm{~b}^{+}$lung dendritic cells in response to fungal infection results from the CCR2-mediated recruitment and differentiation of Ly-6Chigh monocytes. J Immunol 2009, 183:8044-8053

67. Wiley JA, Harmsen AG: CD40 ligand is required for resolution of Pneumocystis carinii pneumonia in mice. J Immunol 1995, 155: 3525-3529

68. Bates JH, Rincon M, Irvin CG: Animal models of asthma. Am J Physio Lung Cell Mol Physiol 2009, 297:L401-L410

69. Hogan SP, Mould A, Kikutani H, Ramsay AJ, Foster PS: Aeroallergeninduced eosinophilic inflammation, lung damage, and airways hyperreactivity in mice can occur independently of IL-4 and allergenspecific immunoglobulins. J Clin Invest 1997, 99:1329-1339

70. Hellings PW, Kasran A, Bullens D, Overbergh L, Mathieu C, Heremans H, Matthys P, Boon L, Jorissen M, Ceuppens JL: IL-10- and IL-12independent down-regulation of allergic sensitization by stimulation of CD40 signaling. J Immunol 2006, 177:5138-5144

71. Chen YQ, Shi HZ: CD28/CTLA-4-CD80/CD86 and ICOS-B7RP-1 costimulatory pathway in bronchial asthma. Allergy 2006, 61:15-26

72. Gordon S: Alternative activation of macrophages. Nat Rev Immunol 2003, 3:23-35 